\title{
Craig Hamilton, Ralf Schneider Od Isera do Turnera i dalej. Na styku teorii recepcji i krytyki kognitywnej
}

\begin{abstract}
Hamilton Craig, Schneider Ralf, Od Isera do Turnera i dalej. Na styku teorii recepcji i krytyki kognitywnej [From Iser to Turner and beyond: reception theory meets cognitive criticism]. „Przestrzenie Teorii” 18. Poznań 2012, Adam Mickiewicz University Press, pp. 221-246. ISBN 978-83-232-2479-2. ISSN 1644-6763.

In this essay, we review the work of Wolfgang Iser, the major proponent of reception theory, and Mark Turner, the major proponent of cognitive criticism. The two theoretical lines advocated by Iser and Turner focus on the cognitive processes involved with reading literary texts. Unfortunately, bibliographic blind spots in both lines lead to the assumption that there is little overlap between reception theory and cognitive criticism. We put this assumption to rest by comparing and contrasting works by Iser and Turner in detail, starting with Iser's work in the mid-1970s and ending with Turner's work in the late 1990s.
\end{abstract}

\section{Wstęp*}

Pójście w kognitywizm - tak można określić jeden z najnowszych nurtów w badaniach literackich. Rzeczywiście, kognitywność stała się wszechobecna, w obiegu funkcjonują takie terminy, jak retoryka kognitywna (Turner), stylistyka kognitywna (Semino, Culpepper)1, poetyka kognitywna (Tsur, Stockwell, Gavins i Steen)2 i teoria kognitywna (Richardson i Crane) $)^{3}$. Na polu literaturoznawczym ma miejsce zauważalny zwrot ku kognitywizmowi albo nawet - jakby to niektórzy ujęli - rewolucja kognitywna (Steen i Richardson)4. Jednakże krytyka kognitywna

* Artykuł ten został napisany w 2002 roku na Uniwersytecie w Tybindze i ukazał się po raz pierwszy w czasopiśmie „Style” 36/4, DeKalb IL 2002, s. 640-658. Craig Hamilton dziękuje Niemieckiej Centrali Wymiany Akademickiej (DAAD) za przyznanie grantu (Kennziffer A102/23707), który pozwolił mu na współpracę z Ralfem Schneiderem nad projektem „Kognitive Rezeptionstheorie/Cognitive Reception Theory” (CoRecT) i napisanie tego artykułu.

${ }_{1}^{1}$ Zob. E. Semino i J. Culpepper (ed.), Cognitive stylistics, Amsterdam 2002.

2 Zob. m.in.: R. Tsur, Toward a theory of cognitive poetics, Amsterdam 1992; P. Stockwell, Cognitive poetics. An introduction, London 2002; J. Gavins i G. Steen (ed.), Cognitive poetics in practice, London 2003.

3 Zob. A. Richardson i M.T. Crane, Literary studies and cognitive science: toward a new interdisciplinarity, „Mosaic” 1999, 32/2, s. 123-140.

${ }_{4}^{4}$ Zob. F. Steen i A. Richardson (ed.), Literature and the cognitive revolution (wydanie specjalne), „Poetics Today” 2002, 23/1. 
(szeroki termin, obejmujący wszystkie formy krytyki literackiej tworzonej w duchu kognitywnym) jak dotąd nie została uznana na zewnątrz i zdefiniowana wewnątrz nurtu jako spójna teoria, jednolity paradygmat albo oficjalna szkoła myślowa. To bez wątpienia taktyka obronna, pozwalająca krytyce kognitywnej kwitnąć. Jak stwierdził ponad dekadę temu Norman Holland, teoria literatury bazowała na „zdyskredytowanym językoznawstwie i wątpliwej psychologii” 5 . Jeśli tak faktycznie było, to zwrot kognitywny miał stać się rekompensatą tego stanu. Ale sukces krytyki kognitywnej może być kwestią dyskusyjną. Korzystanie przez nią z osiągnięć neurobiologii kognitywnej jako narzędzia do opisu może wzmocnić niechęć, jaką humanistyka tradycyjnie żywi wobec nauk ścisłych. Opór wobec krytyki kognitywnej, jak zauważyło wielu naukowców ${ }^{6}$, był więc nie tyle do przewidzenia, ile uznany za bezowocny.

Pierwsze doświadczenia z krytyką kognitywną mogą ujawniać zaskakujące bibliografie. Na przykład Gibbs, Lakoff, Johnson, Tomasello, Rosch, Sperber, Damásio, Edelman i Turner - wszyscy oni usunęli w cień takie autorytety, jak Freud, Saussure, Nietzsche, Piaget, Wittgenstein, Searle, Merleau-Ponty, Husserl i Derrida. Niezwiązani z kognitywizmem akademicy takie zmiany w bibliografii przyjmują sceptycznie. Stało się naturalne, że jeśli w przeszłości popierano argument cytatem z Husserla, dziś cytuje się Damásia. Dlaczego? Przyjmuje się, że wczorajsi filozofowie błądzili, a dzisiejsi neurobiolodzy mają rację. Pokazuje to, jaką fascynację krytycy kognitywni żywią wobec nauki o poznaniu. Z powodu pewnego rodzaju faworyzowania znalezisk $\mathrm{w}$ badaniach dotyczących związku umysłu z językiem nad spekulacjami, ta fascynacja ma rację bytu. Podobnie uzasadnione jest tworzenie teorii literackich na bazie rozsądnej psychologii i wiarygodnego językoznawstwa. Holland czuł, że czegoś takiego desperacko potrzebujemy. Takie połączenie ułatwia także wyjaśnienie naukowego charakteru bibliografii krytyki kognitywnej. Gdy naukę ścisłą włącza się raczej do literaturoznawstwa niż jej obawia, nowe i ulepszone zdaje się bardziej godne zaufania niż stare i zdyskredytowane.

Wciąż istnieje jednak pewna niewyjaśniona luka bibliograficzna w dziedzinie krytyki kognitywnej. Jest nią teoria recepcji. Wyzwanie, jakie Stanley Fish rzucił we wczesnych latach osiemdziesiątych Wolfgan-

5 Cyt. za: T. Wright, Reader-response under review: an art, a game, or a science? „Style” 1995, 29, s. 530.

${ }^{6}$ Zob. m.in.: S. Gross, Cognitive readings; or, the dissapearance of literature in the mind: reviewing reading minds by Mark Turner, „Poetics Today” 1997, 18, s. 271-297; D. Herman, Parables of narrative imagining: a review of the literary mind by Mark Turner, „Diacritics” 1999, 29, s. 20-36; T. Jackson, Questioning interdisciplinarity: cognitive science, evolutionary psychology, and literary criticism, „Poetics Today” 2000, 21, s. $319-347$. 
gowi Iserowi, pomaga wyjaśnić tę lukę. Kiedy Fish ogłosił środowisku literaturoznawczemu, że teoria recepcji jest skazana na porażkę, wielu mu uwierzyło. W marcowym wydaniu czasopisma „Diacritics” z 1981 roku główny przedstawiciel amerykańskiej szkoły rezonansu czytelniczego niepochlebnie zrecenzował książkę The act of reading autorstwa Isera. Argumentował, że kluczowe terminy Iser sformułował $\mathrm{w}$ tak niejasny sposób, by zapewnić sobie „zawczasu zapas strategii obronnych”. Poza tym Iser nigdy nie zajął stanowiska w kwestii tego, gdzie tak naprawdę odbywa się produkcja znaczeń w procesie odczytywania: w tekście, czytelniku, autorze czy może niechlujnym połączeniu tych trzech kategorii? Jak twierdził Fish, Iser nie miał odpowiedzi na te pytania. Co więcej, jego analizy często ukazywały „niedostępność dwóch akontekstualnych jednostek - autonomicznego tekstu i niezależnego czytelnika, których związek obiecuje ukazać". Gdy w swojej replice opublikowanej we wrześniowym wydaniu „Diacritics” z 1981 roku Iser nie zdołał obalić wszystkich zarzutów Fisha, ten postanowił skrócić żywot teorii recepcji. Najpoważniejszą konsekwencją tej porażki było praktyczne zniknięcie z pola widzenia teorii recepcji w wydaniu Isera, choć trzeba zaznaczyć, że ostatnio poświęcono jej całe specjalne wydanie „New Literary History”. Mimo to zniknięcie teorii Isera jest bardziej powszechne na anglosaskich uniwersytetach niż w Niemczech. Brak o niej jakiejkolwiek wzmianki, czy to w formie eseju, czy indeksu, w ważnym zbiorze artykułów (ujmujących jednakże choćby esej Hansa Roberta Jaussa) ${ }^{10}$ dotyczących badań nad recepcją ${ }^{11}$, natomiast $\mathrm{w}$ Niemczech publikacje Isera od lat siedemdziesiątych są niezmiennie dodrukowywane.

Najwyraźniej dziedzictwo teorii recepcji było i jest dość nieszczęśliwe. Już sama nazwa wprawia w konfuzję. W latach siedemdziesiątych, zamiast posługiwać się terminami Rezeptionsästhetik (estetyka recepcji) albo Rezeptionstheorie (teoria recepcji) na określenie swojej Wirkungsästhetik (dosłownie estetyka efektu), Iser nawiązywał, aczkolwiek niechętnie, do teorii rezonansu czytelniczego (reader-response theory). My sami, mówiąc o studiach na tym polu badawczym, wykazujących sporo powiązań z krytyką kognitywną, wolimy używać nazwy teoria recepcji.

${ }^{7} \mathrm{~S}$. Fish, Why no one is afraid of Wolfgang Iser: a review of The act of reading by Wolfgang Iser, „Diacritics” 1981, 11, s. 12-13.

8 Tamże, s. 12.

${ }^{9}$ Zob. R. Cohen (ed.), The writings of Wolfgang Iser (wydanie specjalne), „New Literary History" 2000, 31/1.

10 Zob. H.R. Jauss, Toward an aesthetic of reception, tłum. T. Bahti, Minneapolis 1982.

11 Zob. J. Machor i P. Goldstein (ed.), Reception study: from literary theory to cultural studies, London 2001. 
Jak ujął to Terence Wright, teoria ta nawiązuje do „wielorakich stanowisk, które łączy zainteresowanie tym, co się dzieje w umyśle czytelnika, gdy ten zabiera się za lekturę książki, a potem przegląda ją uważnie"12. Ponieważ taka definicja mogłaby równie dobrze odnosić się do krytyki kognitywnej, ciekawe byłoby zbadanie genezy obu powiązanych dyscyplin. Niniejszy esej zaczynamy od krytycznej recenzji pracy Wolfganga Isera i Marka Turnera, dwójki czołowych przedstawicieli, kolejno, teorii recepcji i krytyki kognitywnej ${ }^{13}$. Następnie przechodzimy do omówienia podobieństw i różnic w poglądach obu badaczy, by w konkluzji zasugerować, że krytyka kognitywna nie powinna ignorować swoich korzeni $\mathrm{w}$ teorii recepcji, a także, by ukazać kierunek wysiłków badawczych w sformułowaniu teorii recepcji kognitywnej.

\section{Recenzja badań Wolfganga Isera}

Początkowo teoria recepcji mogła się wydawać jakimś ruchem praw czytelnika, powstałym $\mathrm{z}$ inspiracji Rolanda Barthesa, który w latach sześćdziesiątych ogłosił „śmierć autora”. Mniej oczywiste było źródło głównego bodźca wzrostu popularności teorii w Niemczech. Uniwersytet w Konstancji, gdy otwierano jego podwoje w późnych latach sześćdziesiątych, miał w swoim założeniu prowadzić badania interdyscyplinarne. Przekraczanie granic dzielących dyscypliny było więc chlebem powszednim dla pracujących w nim naukowców, w tym Wolfganga Isera, dobrze już obeznanego z psychologią, i Hansa Roberta Jaussa, który miał zostać obwołany następnym znaczącym przedstawicielem szkoły recepcji14. $\mathrm{W}$ wyniku ewolucji teorii recepcji, podczas której przeniesiono nacisk z czytelnika na tekst, kwestia praw czytelników stopniowo schodziła na boczne tory. Mimo to Iser wciąż uznawał scenariusz czytania jako układ wzajemnych zależności, rozpoczął więc opisywanie w ogólnym zarysie aktu czytania tekstu przez czytelnika.

Jako że publikacja The act of reading nawiązuje bezpośrednio do pierwszej wydanej w języku angielskim książki Isera The implied reader,

12 T. Wright, dz. cyt., s. 530.

${ }^{13}$ Inni oczywiście już wcześniej wskazywali na mocne i słabe strony obu podejść teoretycznych. Craig Hamilton zajął się recenzją pracy Isera, a Ralf Schneider krytyką Turnera, więc nasza praca nad tym artykułem stanowi dialog przecinający narodowe tradycje akademickie i różne zaplecza edukacyjne.

14 Omówienie przez Isera „horyzontu” (W. Iser, The act of reading: a theory of aesthetic response, Baltimore 1978, s. 96) wskazuje na inspirację badacza sławną koncepcja „horyzontów oczekiwań” Jaussa, choć w swojej książce z 1978 roku Iser nie wspomina nawet o tym pojęciu, sformułowanym po raz pierwszy jeszcze przed wydaniem jego książki. 
nasze omówienie The act of reading nastąpi po komentarzach dotyczących The implied reader. The implied reader koncentruje się na fikcji w ogóle, a w powieści szczególnie, ponieważ „to właśnie w tym gatunku zaangażowanie czytelnicze zbiega się z produkcją znaczenia"15. Ale jeśli tak dzieje się w jakimkolwiek akcie czytelniczym, to skupianie się tylko na fikcji natychmiast ograniczyłoby zakres teorii. Warto jednak omówić ważny rozdział z The implied reader, ten ostatni, zatytułowany „The phenomenology of reading". Iser argumentuje w nim, że każdy tekst zawiera dwa bieguny: „artystyczny nawiązuje do tekstu stworzonego przez autora, natomiast estetyczny do realizacji tekstu osiągniętej przez czytelnika”. Gdzieś pomiędzy oboma biegunami sytuuje się „dzieło literackie”, które czytelnicy tworzą poprzez czytanie bądź „urzeczywistnienie” tekstu. Mimo iż Iser przyznaje, że tego, gdzie ta realizacja ma miejsce, „nie da się dokładnie sprecyzować”16, to za cel obiera sobie właśnie określenie tego miejsca. Zainspirowany pojęciem tekstowych schematów Romana Ingardena, Iser umieszcza pośrednika między tekstem a czytelnikiem, co implikuje liczne konsekwencje. Badacz pisze na przykład o „oczekiwaniach” i „przewidywaniach”17 czytelnika bez żadnej wzmianki o tym, że proces czytania jest intencjonalną albo celową aktywnością poznawczą. Pragnie za to zaprzęgnąć w ramy teoretyczne tą niejasną przestrzeń pomiędzy, to wszechobecne piąte koło u wozu. Jeśli idzie o teksty, to Iser ceni te, które - jak Ulisses Joyce'a - zmuszają czytelnika do „samodzielnego wysiłku"18. Tu badacz niemiecki podziwia w całej rozciągłości pracę czytelnika. Kilka lat później to się zmieni.

Swoją książkę The act of reading z 1978 roku Iser rozpoczyna atakiem na tych, którzy nalegają, by szukać ukrytych znaczeń w tekstach. Jeśli z jednej strony można rozpracowywać teksty podczas czytania, podejmować samodzielny wysiłek, a z drugiej nie należy próbować szukać znaczenia, to postawę Isera trzeba uznać za niejasną. Wielu badaczy tak jak Fish - zwracało uwagę na następujący paradoks: po co najpierw wspierać czytelnika za jego wysiłki zmierzające ku rozpracowaniu tekstu, a potem karać go za wykonywanie tej czynności w celu znalezienia znaczenia? Iser jednakże jeszcze bardziej zaostrza tę kontrowersyjną kwestię $\mathrm{w}$ The act of reading, gdzie żali się, że krytyka literacka często „prowadzi do redukcji tekstów do znaczeń referencyjnych"19. Później stwierdzi jeszcze, że „niekończące się interpretacje sprowadziły [dzieła literackie] do

15 W. Iser, The implied reader, Baltimore 1974, s. xi.

16 Ten cytat i powyższe: tamże, s. 274-275.

17 Tamże, s. 278-279.

18 Tamże, s. 275.

19 Tenże, The act of reading..., dz. cyt., s. 5 . 
poziomu dokumentów, a to $\mathrm{z}$ kolei odarło je z aspektu, który odróżnia je od dokumentów, aspektu, która pozwala nam, czytelnikom, na doświadczenie ducha epoki, warunków społecznych, neuroz autora itd."20. Słowem o największym ładunku emocjonalnym w leksykonie Isera jest zredukowanie, a zarzut, że krytyka redukuje teksty do „poziomu dokumentów” jest w tym przypadku kierowany wobec nowego historyzmu. $\mathrm{W}$ tej kwestii przewidywania Isera się sprawdziły. Jednakże badacz nie zadaje sobie pytania, czemu praktyka interpretowania $\mathrm{w}$ ogóle istnieje. Jeśli, jak stwierdził wcześniej, „interpretacja tekstowa coraz częściej staje się celem samym w sobie"21, to teraz Iser nie jest w stanie wytłumaczyć tego zjawiska. Oczywiście koncepcja „kompetencji literackiej”22 sugeruje, że czytanie literatury jest w dużej mierze skonwencjonalizowane. Zakłada ona, że dany tekst jest oparty na uniwersalnym znaczeniu dotyczącym kondycji ludzkości, a nie życia jednostki. Z jednej strony takie skonwencjonalizowanie może prowokować poszukiwania ukrytego znaczenia, którym przecież Iser tak gardził. Z drugiej strony okazuje się, że nasz system poznawczy jest skonstruowany tak, by widzieć analogię między tekstem a światem, między jedną opowieścią a inną. Innymi słowy, nie możemy wyzbyć się praktyk interpretacyjnych. Omawianie lub wyobrażanie sobie, co jakaś historia może dla nas znaczyć, jest całkowicie naturalne.

Niestety Iser wcale nie uważa tego za naturalne. Zamiast tego skupia uwage na swoim bohaterze - czytelniku implikowanym, który „jest konstruktem i w żadnym razie nie powinien być utożsamiany z jakimś rodzajem rzeczywistego czytelnika"23. To unikanie realnych czytelników, inaczej niż u Hollanda (Five readers reading ${ }^{24}$ ), powoduje przeniesienie wywodów Isera na temat procesu czytania do poziomu stratosfery. To istna pięta Achillesa teorii recepcji z lat siedemdziesiątych: jej prawdziwy obiekt badań wymykał się definicji. Co więcej, nieprzejrzysty styl Isera sprawia, że jego The act of reading jest ciężkie w lekturze. Autor często unika bezpośrednich cytatów z dzieł literackich, których używa jako przykładów, zastępując je pośrednimi relacjami tego, co Fielding napisał w danym fragmencie Toma Jones' ${ }^{25}$. Taka taktyka, uniemożliwiająca nam samodzielne śledzenie eksperymentów czytelniczych Isera, jest ponownie zastosowana $\mathrm{w}$ rozprawie pt. Prospecting from reader response to literary anthropology, gdzie badacz decyduje się na streszczenie frag-

\footnotetext{
20 Tamże, s. 13.

21 Tamże, s. x.

22 J. Culler, Structuralist poetics, New York 1975, s. 114.

${ }^{23} \mathrm{~W}$. Iser, The act of reading..., dz. cyt., s. 34.

${ }^{24}$ Zob. N. Holland, Five readers reading, New Haven 1975.

25 Zob. W. Iser, The act of reading..., dz. cyt., s. 214.
} 
mentu Olivera Twista, zamiast dosłownie przytoczyć słowa Dickensa ${ }^{26}$. Podobne obawy budzi niekończąca się lista kategorii, które według badacza istnieją tylko „w tekście”27, nigdy w naszych umysłach. Wśród nich wymienić można: wędrujący punkt widzenia, temat przewodni, horyzont myślowy, luki i puste przestrzenie, połączenia lub zdolność łączenia, obrazy mentalne pierwszego i drugiego planu, procesy tworzenia obrazów mentalnych, procesy budowania spójności tekstu, strategie oraz repertuar. Mówiąc o repertuarze, Iser ma na myśli konwencje, ale, jak zawsze, unika stosowania konsekwentnie jednego terminu ${ }^{28}$. Dalej stwierdzi, że „w tekstach narracyjnych zwykle zauważyć można cztery podstawowe typy organizacji perspektywy, które można określić jako "przeciwwaga, opozycja, szczebel i seria»"29. Co te metafory znaczą, Iser nie wyjaśnia. Ostatecznie nie wiadomo, jak rozumieć stworzone przez badacza struktury. Iser, za Ingardenem, wierzy w to, że „struktura tekstu literackiego składa się z ciągu schematów"30, które, według Isera, istnieją niezależnie od umysłu, choć jednocześnie - jak zakłada - dopiero rozpoznanie tych schematów pozwala na ich urzeczywistnienie. Co istotniejsze, nie dowiadujemy się, jakie te struktury albo schematy mają znaczenie dla realnych ludzi czytających realne książki.

Kwestia estetyki to kolejny problematyczny aspekt w badaniach Isera. Generalnie, jak twierdzi naukowiec, pierwiastek estetyczny jest wytwarzany tylko wtedy, gdy czytelnik zabiera się za czytanie tekstu. Bez zainicjowania tej czynności nie istnieje. Podczas gdy w jednym fragmencie Iser tłumaczy, że „wartość estetyczna [...] jest jak wiatr - wiemy o jej istnieniu tylko na podstawie efektów, jakie wywołuje"31, w innym pisze: ,jeśli połączymy doświadczenia codzienne z doznaniami estetycznymi, dzieło literackie musi zatracić swój estetyczny pierwiastek i zostać uznane zaledwie za materialne, by ukazać funkcjonowanie lub brak funkcjonowania naszych psychologicznych skłonności" 32 . W podobny sposób literaturę, jako manifestacje „naszych psychologicznych skłonności”, pojmują kognitywiści. Jednakże literatura nie staje się „zaledwie materialna” tylko po to, by udowodnić istnienie tych skłonności; nie znaczy to również - jak obawiają się niektórzy (Dimock ${ }^{33}$ albo Tsur w eseju pt. Event strucs. 14

26 Tenże, Prospecting from reader response to literary anthropology, Baltimore 1989,

27 Tenże, The act of reading..., dz. cyt., s. 21.

28 Zob. tamże, s. 69.

29 Tamże, s. 100.

30 Tamże, s. 227.

31 Tamże, s. 70.

32 Tamże, s. 40.

33 Zob. W.C. Dimock, Forum: reply to Ellen Spolsky, „PMLA” 1999, 114, s. 222-223. 
ture, metaphor, and reductionism ${ }^{34}$ ) - że krytyka kognitywna „redukuje” literaturę do nauk o poznaniu. Z prac Isera ciężko wydobyć jakąś jasną definicję estetyzmu. Nawiązując do poglądu Mukarovsky'ego o tym, że język poetycki odbiega od języka standardowego, autor The act of reading stwierdza z przekąsem, że ta „ortodoksyjna teoria ewidentnie jest przesiąknięta puryzmem - to, co estetyczne w sztuce, jest najprawdopodobniej nieestyczne w życiu codziennym" 35 . Z jednej strony nie powinno się bratać estetyki z codziennością, ponieważ tylko elitarne, a nie przyziemne artefakty kultury należą do kategorii estetyzmu. $Z$ drugiej strony dobre jest łączenie pierwiastka estetycznego w sztuce z pierwiastkiem estetycznym w życiu realnym. Opór wobec takiej praktyki prowadzi do przesadnego puryzmu. Iser kontynuuje wodolejstwo, próbując odróżnić język codzienny od języka literackiego. Raz pisze, że „struktura werbalna mowy literackiej, a szczególnie tej charakterystycznej dla fikcyjnej prozy, jest tak podobna do struktury zwykłej mowy, że często trudno jest je rozróżnić”36. Tym stwierdzeniem podważa prawdziwość tezy o dychotomii pomiędzy językiem literackim a codziennym. Później jednak ta dychotomia okaże się użyteczna, by wykazać, jak niski jest stopień podobieństwa pomiędzy oboma językami ${ }^{37}$. Nic dziwnego, że taki brak konsekwencji wprowadzał czytelników w latach siedemdziesiątych co najmniej w zdumienie.

$\mathrm{W}$ Prospecting from reader response to literary anthropology, poza dwoma pierwszymi rozdziałami napisanymi w latach siedemdziesiątych, Iser zebrał swoje eseje $\mathrm{z}$ lat osiemdziesiątych. I ta publikacja rozpoczyna się atakiem na redukcjonizm i interpretację, bo przecież - jak pisze w niej badacz - historia krytyki literackiej pokazuje, że „interpretacja była właściwa zawsze wtedy, gdy sprowadzała tekst do znaczenia"38. Jego zdaniem, zrozumieć znaczenie tekstu, to źle go odczytać i zredukować do czegoś niegodziwego. Według Isera cała filozofia czytania najwidoczniej zamyka się w „odkrywaniu połączeń i rozwiązywaniu tego, jak tekst narracyjny zdoła zespolić ze sobą oderwane od siebie elementy"39. Twierdzi tak przy jednoczesnym braku zgody na to, że to czytelnicy, a nie teksty, odgrywają rolę pośredników w „zespalaniu elementów” podczas czytania. Najwyraźniej Iser zawsze wzbraniał się przed założeniem, że działanie i intencje należą - jak postulują kognitywiści, tacy jak Daniel Dennett ${ }^{40}$,

${ }^{34}$ R. Tsur, Event Structure, Metaphor, and Reductionism, 1997, esej dostępny na: $<$ http://www.tau.ac.il/ tsurxx/Emily_Dickinson.html> [dostęp: 09.04.2002].

${ }^{35} \mathrm{~W}$. Iser, The act of reading..., dz. cyt., s. 88.

36 Tamże, s. 62.

37 Tamże, s. 183.

38 Tenże, Prospecting..., dz. cyt., s. 3.

39 Tamże, s. 11.

40 Zob. D. Dennett, The intentional stance, Cambridge 1987. 
albo krytycy, tacy jak Norman Holland ${ }^{41}$ - do domeny ludzkiego mózgu. $\mathrm{Na}$ przykład badacz najpierw zapewnia, że ,jeśli powieść nie ujawnia swoich intencji, nie świadczy o braku tych intencji”, by później postawić sobie pytanie o to, „gdzie te intencje znaleźć"42. Człowiek nie jest dla niego nigdy odpowiedzią. Przeciwnie - Iser wyraźnie obstaje przy stwierdzeniu, że „skupianie się wyłącznie na albo technikach użytych przez autora albo psychologii czytelnika mówi nam niewiele o samym procesie czytania"43. Jeśli to nie umysły czytelników i pisarzy mamy badać, to czyj proces czytania Iser próbuje uczynić bardziej teoretycznym? Podczas gdy Holland widział rozwój teorii recepcji w podejściu empirycznym, Iser wolał skierować swoje badania ku wymiarowi stratosferycznemu. Jakkolwiek obcesowo to zabrzmi, zapewnienia Isera o tym, że „teraz jesteśmy w stanie określić z większą precyzją, co właściwie oznacza udział czytelnika w tekście"44, trzeba przyjąć z dużą dozą nieufności.

Jeśli czytelnicy mają niewielkie znaczenie dla badacza niemieckiego, a ich operacje mentalne jeszcze mniejsze, to teoria recepcji w jego wydaniu daleko odbiega od prawdy. Podobne odczucia mieli Holland i Wayne Booth, gdy przeprowadzali wywiad z Iserem, opublikowany jako rozdział trzeci Prospecting. Holland zadał w nim Iserowi kluczowe pytanie: co liczy się jako dowód, skoro empiryczno-psychologiczny dowód jest ignorowany kosztem dowodu wywiedzionego $\mathrm{z}$ fenomenologii lub filozofii? $\mathrm{Na}$ to ważne pytanie badacz niemiecki odpowiada następująco: „opis fenomenologiczny pozwala nam skupić się na procesach układu psychicznego, które pojawiają się nie tylko podczas procesu czytania, ale także w naszych podstawowych relacjach ze światem”, a jego teoria jest oparta na „wyidealizowanym modelu"45, który ze swojej natury musi pozostać abstrakcyjny. Iser sugeruje tu, że metoda, jaką stosuje, ma na celu stworzenie teorii odnoszącej się w większym stopniu do świata, a mniej do tekstów. Ten komentarz, mogący wskazywać na zwrot podejścia badacza ku semiotyce społecznej, jest bardzo interesujący, zwłaszcza w kontekście wątpliwości, jakie Holland wysuwa w kwestii tego, czy na polu teorii recepcji właściwe jest „przyjęcie założenia, że tak nagle można odwrócić nasz cały system poznawczy w przypadku, gdy przeniesiemy się z domeny faktu do domeny fikcji"46. Iser jednakże nie podąża tym tokiem rozumowania. Trzeci $\mathrm{z}$ rozmówców, Booth, także podejmuje ważną kwestię. Przyznaje przy

41 Zob. N. Holland, Where is a text? A neurological view, „New Literary History” 2002, 33, s. 21-38.

42 W. Iser, Prospecting..., dz. cyt., s. 16.

43 Tamże, s. 31.

44 Tamże, s. 40.

45 Tamże, s. 49

46 Tamże, s. 48. 
tym, że jego własne definicje autora implikowanego $\mathrm{w}$ The rhetoric of fiction nie grzeszyły dokładnością ${ }^{47}$. Następnie pyta Isera, jak tamten pojmuje koncepcje czytelnika implikowanego, ponieważ wydaje się, że taki typ czytelnika,jest zawsze podwójną postacią"48. Autor The act of reading zgadza się z taką podwójną rolą czytelnika implikowanego (jako czytelnika-w-tekście i czytelnika), precyzując jednak, że ta kategoria jest mniej związana z czytelnikiem-w-tekście, a bardziej z tym, co się dzieje „za każdym razem, gdy odgrywamy przypisywane nam role poprzez udostępnianie siebie myślom innych, tym samym usuwając swoje własne przekonania, reguły i wartości na drugi plan"49. Innymi słowy, Iser zestawia w jednym szeregu czytelnika implikowanego z czytelnikiem realnym, a przy okazji przywołuje tak bardzo deprecjonowany przez siebie koncept czytelnika biernego. Tak jak w przypadku odpowiedzi na pytanie Hollanda, tak i tu badacz niemiecki wyraża coraz bardziej entuzjastyczną opinię o czytelniku biernym, ponieważ wzmacnia to rolę tekstu w pośredniczeniu. Podczas gdy Barthes swego czasu mógł mieć nadzieję na pomniejszenie roli pośredniczącej autora kosztem zwiększenia roli pośrednictwa czytelnika, Iser zwiększa wagę pośrednictwa tekstu najwyraźniej kosztem roli pośredniczącej czytelnika. W tej kwestii można zauważyć pełną konsekwencję badacza. W końcowym rozdziale Prospecting ujęto również odpowiedzi Isera, które padły podczas wywiadu udzielonego Fishowi, jednak ten ostatni wycofał zgodę na opublikowanie swoich pytan, przez co odpowiedziom Isera brakuje kontekstu.

Pomimo dozy tajemniczości i rażącego braku klarowności stylu Isera, Prospecting można uznać za najbardziej przystępną z jego książek. Zawiera ona także kilka najbardziej inspirujących idei badacza. Wright miał poczucie, że „Fisha przynajmniej przyjemnie się czytało”, a Isera przeciwnie ${ }^{50}$. Taka opinia jest jednak krzywdząca. Pod koniec lat osiemdziesiątych, gdy badacz niemiecki zaprzestaje prób tłumaczenia procesu czytania, jego styl diametralnie się poprawia. W Prospecting pisze na przykład:

Ponieważ literatura jako medium istnieje mniej więcej od momentu, gdy zaczęto rejestrować czas, jej obecność musi najprawdopodobniej być oznaką pewnych antropologicznych potrzeb. Jakie są te potrzeby i co to medium mówi nam o naszej antropologicznej charakteryzacji? To są pytania, które prowadziłyby do rozwinięcia antropologii literatury ${ }^{51}$.

47 Tamże, s. 59

48 Tamże.

49 Tamże, s. 63.

50 T. Wright, dz. cyt., s. 540.

51 W. Iser, Prospecting..., dz. cyt., s. 50. 
Tu wreszcie odnajdujemy klarownego i fascynującego Isera. „Potrzebujemy fikcji” - twierdzi on - ponieważ rolą fikcji ,jest tłumaczyć”52, umożliwiać nam wprowadzanie w życiu porządku nad chaosem. Nie mamy pojęcia na temat swoich narodzin i śmierci, ale wiemy na pewno o nieuchronności śmierci. Trudność w zrozumieniu sensu naszej egzystencji prowadzi nas do opowieści i fikcji, czyli źródeł wiedzy o naszym życiu, o okresie pomiędzy narodzinami a śmiercią. Fikcja służy więc jako forma „zamaskowywania” i „demaskowania”53, która pozwala nam odróżnić „świat tekstu” od „świata przez ten tekst przedstawiony”54 i w rezultacie lepiej zrozumieć nasz świat. W centrum świata umysłu fikcja jest więcej kluczem, a nie ornamentem. Iser ujmuje to następująco: „fikcja literacka okazuje się paradygmatyczną manifestacją wyobrażonego" 55 . To już zapowiada obiecującą podróż badacza w stronę antropologii literackiej, głównego tematu jego kolejnej książki.

Tak jak ostatni rozdział The implied reader przetarł ścieżkę dla The act of reading, tak finalny rozdział Prospecting utorował droge dla The fictive and the imaginary: charting literary anthropology z 1993 roku, książki, która zawiera kilka dobrych rozdziałów, choć Wright wyrażał opinię, jakoby „odnośniki Isera były prawdopodobnie jej najbardziej czytelną częścią” 56 . Tę publikację badacz opatrzył wstępem przestrzegającym przed pojmowaniem literatury jedynie ,jako środka propagowania oświecenia społecznego, co sprowadza ją do statusu dokumentu"57. I tym razem Iser sugeruje, że redukcja jest zła. Zauważa również, że „sztuka zdaje się niezbędna jako narzędzie do autointerpretacji ludzkości"58. Binarną opozycję fikcja - rzeczywistość proponuje zastąpić triadą złożoną z pierwiastków rzeczywistego, fikcyjnego i wyobrażonego ${ }^{59}$ celem ożywienia wyobraźni i zbadania jej związku z fikcją. Dochodzi do wniosku, że pewien stopień zrozumienia znaczenia jest możliwy, jeśli zaakceptujemy założenie, że „upragmatyzowanie wyobrażonego" to konsekwencja naszych „oczekiwań dotyczących znaczeniowości” literatury60, konceptu, który ponownie wtóruje konwencjom czytelniczym Cullera. Dla Isera wy-

52 Tamże, s. 265.

53 Tamże, s. 268.

54 Tamże, s. 272.

55 Tamże, s. 277.

56 T. Wright, dz. cyt., s. 541.

$57 \mathrm{~W}$. Iser, The fictive and the imaginary: charting literary anthropology, Baltimore 1993, s. x.

58 Tamże, s. xiii.

59 Tamże, s. 1.

60 Tamże, s. 18. 
obraźnia jest zorientowana na pragmatykę, by tworzyć znaczenie podczas obcowania z fikcją literacką, nawet jeśli domniema się, że pośrednikiem narzucającym intencje na treść wyobrażoną nie jest wyobraźnia sama $\mathrm{w}$ sobie ${ }^{61}$. To wszystko zgadza się $\mathrm{z}$ dyskusją Isera $\mathrm{w}$ trzecim rozdziale na temat funkcji fikcji w filozofii. Badacz uważa, że fikcja jest niezbędna wielu filozofom (na przykład Baconowi, Benthamowi, Vaihingerowi, Goodmanowi), nawet w przypadku, gdy ci ją lekceważą, natomiast o utworach fikcyjnych sądzi, że są pożyteczne - pomagają „działać ludziom ponad ich możliwościami” ${ }^{2}$, z czym czytelnicy specjalnego wydania czasopisma "Poetics” pod redakcją Steena i Richardsona ${ }^{63}$ mogliby się zgodzić. Fikcja, jak argumentuje Iser w innym fragmencie, jest „kameleonem poznania, co oznacza, że jako pewien zestaw narzędzi do naprawy konceptualizacji nieuchronnie musi wyjść poza pojęcia, które próbuje objąć"64. Choć niewidoczny, taki kameleon okazuje się obecny nawet wtedy, gdy zdaje się operować tylko na poziomie poznawczym.

Czwarty rozdział The fictive and the imaginary obfituje w przydatne informacje na temat historii wyobraźni jako konceptu z zakresu estetyki. Iser szczegółowo analizuje w nim ewolucję terminów wyobraźnia i wyobrażone od Arystotelesa, przez Coleridge'a, aż do Sartre'a. W przedostatnim rozdziale, zatytułowanym „Text play”, bierze na warsztat cztery kategorie gry Caillosa (agon - współzawodnictwo, alea - los, mimicry naśladowanie, ilinx - oszołomienie) i próbuje odnieść je do literatury ${ }^{65}$. Trzeba to właśnie nazwać próbą, ponieważ w tekście próżno szukać przykładów literackich. Zamiast tego, te różne typy gier pokazują, że kiedy czytamy, traktujemy teksty jak gry i że teksty w rewanżu grają nami, czytelnikami. Według Isera kiedy czytamy, wszystkie cztery kategorie gry regularnie wzajemnie oddziałują na siebie, począwszy od gry wolnej, aż do kontrgry. Czytanie jest więc „uczestniczeniem w grze i byciem pionkiem w grze"66. Choć Wright zgryźliwie puentuje te przemyślenia, mówiąc, że „nikt w historii teorii literatury nie był w stanie pisać z taką powagą na temat grania"67, to jednak komentarze Isera dotyczące związ$\mathrm{ku}$ literatury z koncepcją gier są warte uwagi. Definiując grę w literaturze (wspomniana jest koncepcja przyjemności z tekstu Barthesa) jako ważny aspekt antropologii literatury, Iser prezentuje ciekawe twierdze-

61 Tamże, s. 223.

62 Tamże, s. 170.

${ }^{63}$ Zob. F. Steen i A. Richardson (ed.), dz. cyt.

${ }^{64} \mathrm{~W}$. Iser, The fictive..., dz. cyt., s. 165.

65 Tamże, s. 259.

66 Tamże, s. 271.

67 T. Wright, dz. cyt., 540. 
nie: opowieści i gry są uniwersalne i jako takie muszą być produktami rudymentarnej ludzkiej psychologii. Jeśli tak faktycznie jest, powinny być ujęte w odpowiednie ramy teoretyczne. Wysiłki Isera w tym kierunku zapowiadają obecne zainteresowania krytyki kognitywnej kategoriami fikcji, gry i ewolucji68. W ten sposób późne prace badacza niemieckiego prowadzą logicznie do badań krytyki kognitywnej.

\section{Recenzja badań Marka Turnera}

W wielu swoich publikacjach, szczególnie w trzech książkach poddanych analizie w niniejszym artykule, Mark Turner rozwija podejście teoretyczne łączące w sobie językoznawstwo, krytykę literacką i kognitywizm. Rozpoczyna od założenia, wedle którego to szczególnie badania literackich środków ekspresji (takie jak metafora, analogia lub parabola) mogą doprowadzić do wykrycia ogólnych mechanizmów myślowych. Takie podejście koliduje bezpośrednio ze statusem literatury i, równolegle, ze statusem krytyki literackiej. Jeśli więc podążamy za Turnerem, obie dyscypliny wymagają przeformułowania. Dla tego badacza codzienne poznanie i ekspresja literacka wyrastają z tych samych zasad myślowych, które z kolei wywodzą się z najbardziej fundamentalnych interakcji cielesności ludzkiej ze środowiskiem. Tak więc studia nad literaturą u swojej podstawy są - albo raczej powinny być - podobne do badań procesów myślowych człowieka (zdefiniowane przez Turnera jako „umysł w mózgu w ciele”). Skupiwszy się na analizach metaforycznych środków ekspresji i zrozumienia, Turner jeszcze bardziej odszedł od swojego głównego obiektu badań - literatury, stając się tym samym bardziej kognitywistą niż krytykiem literackim (pogląd ten wzmacnia dodatkowo fakt niedawnej współpracy badacza z Gillesem Fauconnierem).

Death is the mother of beauty: mind, metaphor, criticism, pierwsza książka Turnera z 1987 roku, wysuwa argument dla powstania „nowoczesnej retoryki" dla powszechnych procesów językowo-konceptualnych poprzez odkrywanie w szczególności interpretacji i pojmowania metafor pokrewnych (przykładem jest tu metafora Wallace'a Stevensa, użyta w tytule książki Turnera). Na przekór tradycyjnej retoryce amerykański badacz uważa „metaforę nie tylko jako zjawisko leksykalne [...] ale raczej jako podstawowy środek poznawczy, wpływający na całość ludzkiej myśli

68 Zob. H. Porter Abbot (ed.), On the origin of fiction: interdisciplinary perspectives (wydanie specjalne), „Substance” 2001, 30/1-2; F. Steen i A. Richardson (ed.), dz. cyt. 
i działania, obejmujący język codzienny i język poetycki”69. Studia nad metaforą (czy to na podstawie analizy przysłów, czy literatury) powinny $\mathrm{w}$ rezultacie umożliwić wgląd w mechanizmy myślowe. Nawiązując do tradycji lingwistycznej, Turner korzysta z fragmentów mowy jako surowca do rekonstrukcji procesów myślowych, które najpierw doprowadziły do powstania badanej wypowiedzi. To, co badacz mówi w tym momencie na temat literatury, usatysfakcjonuje większość krytyków literackich:

potęga dobrej literatury wynika z jej mistrzowskiej zdolności do przywoływania i zręcznego kierowania naszym aparatem poznawczym [...] istnieje pewna część wiedzy na temat umysłu ludzkiego, jaką to właśnie literatura jest w stanie najlepiej ukazać. [...] To, czego chce nas nauczyć autor, może być nabyte tylko poprzez badanie literatury, a takie zadanie leży w gestii krytyka literackiego, wykształconego w tym kierunku, a nie psychologa bądź językoznawcy kognitywnego ${ }^{70}$.

Jak zauważymy później, od kiedy krytyka literacka jako dyscyplina traci dla Turnera na znaczeniu, są powody, by podejrzewać, że badacz byłby dziś mniej skłonny wygłaszać powyższe poglądy. W cytowanych fragmentach jego wypowiedzi literatura jawi się jako kategoria wyjątkowa, nie w kontekście tego, jakie procesy myślowe wykorzystuje, ale w jaki sposób to robi. Turner zarzuca krytykom literackim błędne pojmowanie literatury jako aktywności odrębnej od tych, które obejmują myślenie pojęciowe:

Krytyk zwyczajowo przeskakuje te fragmenty, gdzie tekst wydaje się jednoznaczny a odczytanie naturalne, chyba że uda się wprowadzić jakieś zrozumienie, które skomplikuje tę jednoznaczność lub uczyni tę naturalność obcą. Ale ten krytyczny przeskok omija ważniejsze pytanie, które powinno pojawić się wcześniej: jak tekst w ogóle może wydawać się jednoznaczny? ${ }^{71}$.

Żeby dotrzeć do źródeł mechanizmów ujawniających przede wszystkim, jak rozumiemy dany tekst, Turner naszkicowuje podejście teoretyczne, które można nazwać strukturalizmem koncepcyjnym: badacz szuka ukrytych wzorów czy głębokich struktur umożliwiających wytwarzanie, przetwarzanie i pojmowanie pojedynczych metafor (w omawianej publikacji szczególnych metafor pokrewnych), które różnią się na poziomie językowym. Widać wyraźnie, że Turner jest

zainteresowany wzorcami znaczenia przewijającymi się przez wszystkie metafory pokrewne. Te wzorce wykraczają poza lokalne zjawiska tekstualne, ponieważ s. $3-4$.

69 M. Turner, Death is the mother of beauty: mind, metaphor, criticism, Chicago 1987,

70 Tamże, s. 9.

71 Tamże, s. 10. 
są częścią naszej poznawczej zdolności rozpoznawania metafor i naszych kognitywnych modeli pokrewieństwa, których źródłem jest nasza przynależność i udział w językowych i literackich społecznościach ${ }^{72}$.

Jak wskazuje George Lakoff w przedmowie ${ }^{73}$ do Death is the mother of beauty, to, co odróżnia Turnera od większości strukturalistów, to fakt, że odrzuca on proste strategie analizy semantycznej, jakie królowały we wcześniejszych podejściach do metafory (np. badania nad wyróżnianiem cech semantycznych). Zamiast tego utrzymuje, że procesy związane z metaforą mogą być opisane jako „zlewanie” (blending), „mapowanie” (mapping) i „rzutowanie” (projecting) domen konceptualnych na i w siebie. To terminy często używane przez Turnera.

Kwestią problematyczną jest to, że Turner, tak jak Iser, a faktycznie ktokolwiek zajmujący się rozumieniem języka, bada w wysokim stopniu zautomatyzowane i nieświadome strategie przetwarzania informacji. Jako że są one niedostępne świadomej weryfikacji, opisywanie pojedynczych działań aparatu mentalnego w prawdziwym detalu jest raczej niemożliwe. Zamiast tego Turner ujmuje te procesy w metafory („zlewanie”, „mapowanie” i „rzutowanie”). Widać więc, że choć określa operacje aparatu mentalnego dokładniej niż Iser, to wyjaśnienie, jak te procesy przebiegają, wciąż jest niełatwe. Uciekanie się Isera do modeli psychologicznych poprzedniego paradygmatu może być usprawiedliwione, zważywszy na to, że naukowiec opublikował swoje książki zanim zwrot kognitywny wskrzesił naukę o ludzkim umyśle, natomiast Turner w zaskakująco niewielkim stopniu wspiera się osiągnięciami psychologii kognitywnej74, mimo że ma przywilej pisania w kontekście żywych badań prowadzonych na polu nauki o poznaniu. Innymi słowy, badacz amerykański czasem chętniej zwraca się ku filozofii języka niż psychologii myśli. Tam, gdzie Iser niedookreślił swojej koncepcji czytelnika, Turner konsekwentnie podkreśla wiarygodność swojej teorii poprzez inkluzywność. Za każdym razem, gdy opisuje, co czytelnicy/słuchacze robią podczas myślenia, mówienia i słuchania, naukowiec używa zaimka w pierwszej osobie liczby mnogiej: my przenosimy nasze cielesne doświadczenia na domeny abstrakcyjne, nasz aparat konceptualny jest ukształtowany w ten albo inny sposób itd.

72 Tamże, s. 13.

73 Tamże, s. x.

74 Trudno usprawiedliwić to, że Turner, tak jak i Iser, nie aktualizował następnych wydań swoich rozpraw. Badacz amerykański nie podejmuje żadnej próby umiejscowienia opisów aktów czytania w ostatnich odkryciach psychologów na temat przetwarzania informacji. 
Według Turnera bloki konstrukcyjne, które stanowią „naszą” zdolność do wyrażania i rozumienia szerokiej gamy zjawisk, to metafory pojęciowe, takie jak PRZYCZYNA JEST ZAPŁADNIANIEM I WYDARZENIA SĄ AKCJAMI, w których zderzają są ze sobą dwie domeny konceptualne, by później zostać użyte na przykład do formułowania przyczynowych twierdzeń. Zakładając istnienie takich podstawowych metafor, Turner odpowiada na drażliwą filozoficzną kwestię przyczynowości. Jednakże jego podejście niezmiennie balansuje pomiędzy pozycją uniwersalistyczną a kulturową. Z jednej strony twierdzi, że „abstrahując od artefaktów, kultura znajduje swoje ucieleśnienie w umyśle"75, co sugeruje, że świadomość kulturowa - założywszy uniwersalność naszej biologicznej „obudowy" - jest zaprogramowana u wszystkich ludzi tak samo, bez względu na ich kulturowe pochodzenie i mentalność. $\mathrm{Z}$ drugiej strony badacz powie później, że „główną obserwacją antropologii kognitywnej jest fakt, że by zbadać kulturę, trzeba zbadać proces poznania, czyli struktury pojęciowe używane przez członków danej kultury"76. Ta wypowiedź pokazuje, że Turner jest świadom różnorodności kulturowej charakteryzującej wzorce myślowe, jednak jest nimi mało zainteresowany. Nawet gdyby zaakceptować, że myśl ucieleśniona wskazuje na uniwersalnie niezmienny aparat mentalny, to czy nie byłoby jednak bardziej frapujące badanie tego, jak i dlaczego członkowie poszczególnych kultur mogą stosować różne struktury pojęciowe? Podczas gdy Turner pewnie zdawał sobie sprawę, że jego książkę mogliby czytać członkowie kultur niezbyt zadowolonych z nieustannego używania przez badacza formy „my”, to raczej nie był świadom tego, że przedstawiciele różnych narodowych literackich tradycji (albo innych przejawów jakiejś kultury) mogą słusznie zastanawiać się, jak balansować między uniwersalizmem a różnorodnością kulturową.

Turner brzmi przekonująco w swojej analizie metafor pokrewnych. Zgromadził pokaźny materiał badawczy i czerpie ze swoich analiz główne wzorce wnioskowania wyrastające z pojęć pokrewnych, najbardziej popularne użycia metafor pokrewnych oraz utrudnienia w mapowaniu pojęć. Poprzez ilustracje literackie (od Raju utraconego Miltona, poprzez Faeire queene Spensera, aż do Teogonii Hezjoda), badacz amerykański pokazuje, że podstawowe metafory pokrewne dostarczają narzędzi do zrozumienia, jak jedne rzeczy w świecie wynikają z innych. Według niego takie teksty, jak Raj utracony mają sens dla czytelników, ponieważ w momencie, gdy czytelnicy zabierają się za ich czytanie, są wyposażeni w zestaw podświadomych struktur pojęciowych, które automatycznie stosują przy ob-

75 Tamże, s. 13.

76 Tamże, s. 14. 
cowaniu z tymi tekstami. Te mechanizmy utykają w martwym punkcie dopiero wtedy, gdy czytelnicy muszą sformułować nieoczekiwane, odbiegające od normy wnioski. Takie przypadki ukazują samo sedno istnienia pewnych procesów kognitywnych.

Swoją drugą książkę Reading minds z 1991 roku Turner trafnie opatrzył podtytułem The study of English in the age of cognitive science [Nauka języka angielskiego w erze nauki o poznaniu]. Zamiast analizować w niej status quo nowej dyscypliny, badacz wskazuje drogę, która ma prowadzić do kontynuowania tzw. badań wokół języka angielskiego. Reading minds nie tylko rozpoczyna się tym, czym kończy się poprzednia książka, ale też powiela wiele z podstawowych argumentów w niej zawartych. Celem drugiej publikacji książkowej Turnera jest reforma profesjonalnej nauki o języku angielskim, zakotwiczenie i ugruntowanie jej w badaniach nad umysłem człowieka. Zdaniem autora Reading minds,

naszej dyscyplinie brakuje koncepcji języka i literatury jako codziennych przejawów działania ludzkiego umysłu. Gdybyśmy mieli taką koncepcję, nasza aktywność naukowa koncentrowałaby się przede wszystkim wokół studiów nad językiem i literaturą jako werbalizacją naszego aparatu kognitywnego ${ }^{77}$.

Takie studia umysłu-poprzez-język-i-literaturę pokrywają się z istotnymi pytaniami zadawanymi na polu teorii recepcji:

[...] najbardziej niesamowitym, a zarazem najmniej wyjaśnionym zjawiskiem, któremu stawia czoło nasza profesja, jest to, że czytelnik jest w stanie zrozumieć tekst i że każde takie pojedyncze pojmowanie danego tekstu ukazuje pewne regularności. Jak tego dokonują czytelnicy?78

Nie jest łatwo odpowiedzieć na to pytanie. Iser próbował i poległ. Turner odszukuje potencjalne odpowiedzi w procesach metaforycznych i rozumowaniu poprzez analogie, czym sugeruje szerokie zastosowanie swojej metodologii. By zademonstrować79, że „rozum i myśl poetycka wcale wzajemnie się nie wykluczają" ${ }^{\circ 0}$, ponownie podaje liczne przykłady tego, jak kilka podstawowych metafor i schematów wyobrażeniowych („formy

77 Tenże, Reading minds: the study of English in the age of cognitive science, Princeton 1991, s. 6.

78 Tamże, s. 19.

79 Na przykład Turner pisze, że „podejście kognitywne do aktów językowych i literackich mogłoby potencjalnie służyć jako wspólny grunt dla wielu różnych teorii literatury, nie będąc w sprzeczności z żadną z tych teorii, mimo swojej wzajemnej niekompatybilności. [...] Takie podejście kognitywne do języka mogłoby być przyczynkiem dla badaczy analizujących kulturowe, socjologiczne i psychologiczne modele i procesy mentalne, które objaśniają język"; tamże, s. 22.

80 Tamże, s. 20. 
szkieletu, które strukturyzują nasze wyobrażenia"81) jednocześnie umożliwia i ogranicza szeroki zakres procesów myślowych obecnych w codziennym myśleniu i przejawach literackiego wyrazu.

Turner mocno postuluje stworzenie nowego i ekscytującego projektu humanistycznego, ale sposób sformułowania apelu może szkodzić jego celom. Podczas gdy Iser abstrakcyjnie mistyfikuje, jego amerykański kolega konkretnie demistyfikuje, mnożąc pedantycznie wyselekcjonowane przykłady. I mimo że w ten sposób Turner pragnie rozwiać wszelkie wątpliwości wynikające z podawania przez czytelników kontrprzykładów, to tak naprawdę czytanie jego argumentów może być męczące ${ }^{82}$. Co więcej, styl argumentacji badacza często opiera się na sylogizmach: nieśledzenie każdej przesłanki może powodować brak zrozumienia pozostałej części argumentu. Także jego próby zakotwiczenia pewnych mechanizmów myślowych w układzie ciała i jego relacji w stosunku do świata mogą prowadzić do naciągania hipotez. Choćby twierdzenie Turnera o tym, że proces, który umożliwia nam dedukowanie, jest ugruntowany $\mathrm{w}$ prawo-lewej symetrii ciała ${ }^{83}$, po prostu przesądza sprawę. Dla kontrastu, kiedy tylko badacz szuka poparcia dla swoich argumentów w nauce o poznaniu, jego tezy zyskują na wiarygodności, nawet jeśli badania mózgu jak dotąd wygenerowały frustrująco niewiele solidnych informacji na temat tego, jak funkcjonują konkretne procesy rozumienia. Mimo że kognitywno-psychologiczne eksploracje działania mózgu wciąż mogą okazać się niekompletne i niewystarczające, Turner nie ma zamiaru uzupełniać swoich rozważań dotyczących procesów mentalnych osiągnięciami pokrewnych pól badawczych, by wymienić tu choćby wiedzę o przetwarzaniu dyskursu albo wiedzę o poznaniu i emocjach. Nawet w kontekście zwrotu kognitywnego i fascynacji kognitywizmem krytycy literaccy biorący się za lekturę Turnera muszą powątpiewać $\mathrm{w}$ to, że badania literackie ${ }^{84}$ mogłyby przejść radykalną metamorfozę i być podporządkowane badaniom nad myślą. Nie oznacza to oczywiście, że próżno szukać u badacza amerykańskiego niezwykle obiecujących pól badawczych.

Turner argumentuje, że pojedyncze frazy stanowią bardzo użyteczny materiał do analiz kognitywno-retorycznych, a skoro w poezji można za-

81 Tamże, s. 57.

82 Tu mamy typowy przykład retoryki stosowanej przez Turnera: „człowiek to wzorce działań umysłu i mózgu. Kultura, społeczeństwo, podmiotowość, sztuka, taniec i wszystkie tematy podejmowane przez humanistykę są wzorcami działań umysłu i mózgu. Badania humanistyki są więc u swojej podstawy badaniami nad umysłem i mózgiem”; tenże, The literary mind, New York 1996, s. 48.

83 Tamże, s. 70-74, 89.

84 Tamże, s. 149 i nn. 
uważyć największe zagęszczenie metafor ujętych w krótkie segmenty językowe, to właśnie wiersze stają się dla niego najbardziej naturalnym materiałem analitycznym. Ale jego podejście mogłoby też być stosowane na bardziej złożonym poziomie, tzw. poziomie kontrolującego sprzężenia konceptualnego (powszechnie znanego pod nazwą rozbudowanej metafory), którego praktyczną ilustracją jest na przykład „związek między błyskotliwością konwersacyjną a seksem w Wiele hałasu o nic"85 albo między transakcjami biznesowymi a flirtem w wielu angielskich komediach z przełomu XVII i XVIII wieku. Na szerszą skalę możliwe, że wszystkie trzy wspomniane procesy - mapowania, rzutowania i zlewania - odgrywają pewne role $\mathrm{w}$ badaniach gatunkowych. Jednakże tu propozycje Turnera nagle się urywają, ponieważ badacz stwierdza, że lepiej będzie „pozostawić w gestii czytelnika kwestię tego, jakie inne formy jego projekt może przyjąć"86.

Niewiele takie stwierdzenie pomaga $\mathrm{w}$ rozumieniu literatury, prócz uświadomienia nam, że jest ona nie tylko mniej wyjątkowa niż wielu chciałoby wierzyć, ale też bardziej czasoprzestrzennie uniwersalna i stabilna. Na pewno fundamentalną kwestią, jaką Turner powinien poruszyć w swojej rozprawie Reading minds, jest przed wszystkim, dlaczego literatura i obcowanie z nią powinny być potrzebne umysłom ludzkim. Na ten temat Turner wspólnie z Iserem powinni byli przeprowadzić ważną rozmowę około lat dziewięćdziesiątych, czyli wtedy, gdy badacz niemiecki próbował szukać odpowiedzi na powyższe pytanie. Być może przeszkodą była sama literatura, choć trudno to stwierdzić, biorąc pod uwagę niejasną definicję tego terminu podawaną przez Turnera. Na przykład skoro „myśl poetycka stanowi część myśli codziennej, a język poetycki stanowi część języka codziennego" i skoro „to, co poetyckie, wyrasta z tego, co codzienne”, więc „by zrozumieć pierwiastek poetycki, musimy zrozumieć istotę codzienności”" to po co wysuwać twierdzenie, że „literatura jest najwyższą formą ekspresji naszych powszednich i językowych zdolności”88 albo w ogóle nawiązywać do „wielkich pisarzy” [wyróżnienie - C.H. i R.S.]? Będąc ograniczeni ramami teoretycznymi podejścia kognitywnego, równie dobrze możemy argumentować, że jesteśmy stworzeni do wydawania ocen na podstawie metafor pojęciowych zrównujących ilość z jakością (GÓRA TO DOBRZE, DÓŁ TO ŹLE). Niemniej jednak nie zwolni nas to od obowiązku sprecyzowania - jeśli w ogóle chcemy się nimi posługiwać - naszych kryteriów doskonałości (najwyższa albo wielka)

\footnotetext{
85 Tamże, s. 149.

86 Tamże, s. 150.

87 Tamże, s. 49.

88 Tamże, s. 13.
} 
albo tego, co uznajemy za literaturę. Chociaż Turner mógł podjąć tę kwestię już wcześnieje9, unikając wartościujących kategoryzacji literatury (takich jak wysoka, niska, dobra, zła), to teraz - w obliczu jego krytyki prac Erica Donalda Hirscha i wojen toczonych o kanon literacki w ostatnim rozdziale Reading minds - podjęcie tej problematyki jest szczególnie istotne.

Dalsza dekonstrukcja rozróżnienia pomiędzy umysłem zaangażowanym w sprawy codzienne a umysłem literackim następuje w książce The literary mind (1996) ${ }^{90}$. Opis na tylnej okładce (oprawa miękka) zapowiada rozprawę bardziej zorientowaną kognitywnie niż literacko, ale czy powinniśmy oceniać książki po ich okładkach? Dla niewtajemniczonych The literary mind może się wydawać brawurowa i odważna, ale argumenty w niej zawarte na pewno nie zdziwią czytelników znających poprzednie publikacje Turnera. W całej omawianej rozprawie badacz próbuje udowodnić, że umysł jest u swej podstawy literacki, ponieważ te same procesy, które umożliwiają ludziom myślenie, dotąd były błędnie łączone z literackością. Turner rozszerza pole swoich działań badawczych na kategorię, którą nazywa „podstawowym instrumentem myślowym”1, czyli zdolnością myślenia kategoriami opowieści (wyobrażanie narracyjne) i rzutowaniem jednej opowieści na drugą (proces ten określa jako parabolę). Takie propozycje powtarzają się w całej książce: „instrument mentalny, który nazywam utworem narracyjnym czy opowieścią, jest zasadniczym składnikiem ludzkiego myślenia” albo „instrument mentalny, który nazywam parabolą, jest w najszerszym zakresie użytkowany przez powszedni umysł"92. Tak jak w przypadku podstawowych metafor i rdzennych schematów wyobrażeniowych, które w swoich poprzednich książkach Turner postrzegał jako bazę do bardziej wymyślnych i specyficznych metaforycznych użyć, tak i tu mamy do czynienia z prototypowymi opowieściami i pierwotnymi narracjami prostych działań wykonanych w czasoprzestrzennym kontinuum, które są blokami tworzącymi bardziej skomplikowane struktury myślowe. Według badacza, te narracje są wykorzystywane w (nieświadomych) praktykach mentalnych, takich jak przewidywanie, ocenianie, planowanie i wyjaśnianie. Jeśli chodzi o metafory, to opowieści są ugruntowane $\mathrm{w}$ interakcjach jednostki ze światem:

Nie jest możliwe, by niemowlę nie było w stanie pojąć na przykład konceptu działania zbiornika albo płynu i wlewania, albo przepływania, albo ścieżki, albo

89 Zob. tenże, Death..., dz. cyt., s. 78-79.

90 Tenże, The literary mind, dz. cyt.

91 Tamże, s. 4.

92 Tamże, s. 7. 
ruchu wzdłuż ścieżki, albo produktu tych konceptów: małych rozmiarów przestrzennych opowieści, w których płyn jest wylewany, by później przepłynąć wzdłuż ścieżki do pojemnika ${ }^{93}$.

W ten sposób Turner przekonująco ukazuje, jak takie rudymentarne opowieści przestrzenne i inne leżące $u$ podłoża procesy mentalne (szczególnie schematy wyobrażeniowe) uruchamiają literacką i nieliteracką myśl.

W omawianej książce znajdziemy też rozdziały podejmujące temat amalgamacji przestrzeni mentalnych, zamysłu, który szczegółowo został przedstawiony przez Fauconniera i Turnera w ich The way we think ${ }^{94}$ jako wzajemne oddziaływanie i konstrukcja nowych pojęć w umyśle. Amalgamacja, czy też stapianie, jako teoria opisuje ostateczne produkty działań mentalnych i próbuje ustalić związane z tymi działaniami procesy psychologiczne. O ile Turner tłumaczy na przykład, że „stopione przestrzenie wykonują czynności poznawcze w najmocniejszym znaczeniu" i że „dostarczają wniosków, emocji i nowych akcji”, to już sam sposób dostarczania przez te przestrzenie wniosków itd. pozostaje niedopowiedziany.

Po lekturze trzech książek Turnera nasze wątpliwości budzi też użycie przez badacza synonimicznych terminów. Podczas gdy w Death is the mother of beauty Turner trzyma się konsekwentnie pojęcia metafory, to już w Reading minds używa analogii jako „terminu parasola obejmującego wszystkie przypadki odpowiadające naszemu rozumieniu jednego konceptu przez pryzmat drugiego" ${ }^{96}$. W ostatniej dyskutowanej książce, The literary mind, naukowiec znów rezygnuje z metafory i zamiast tego omawia parabolę. Według Turnera, powyższe terminy i procesy nie tylko prowadzą do powstania opowieści narracyjnych, ale także do rozwoju języka i gramatyki. Trudno się jednak oprzeć wrażeniu, że termin literacki w tym kontekście jest zbędny. Jeśli wszystkie działania mentalne ludzi mogą być ujęte jako literackie, to literatura okazuje się mieć znaczenie synonimiczne $\mathrm{z}$ myślą, a teksty literackie $\mathrm{z}$ „myślami w książkach". W podsumowaniu swoich rozdziałów na temat stapiania przestrzeni Turner jeszcze raz podkreśla swoje credo: „procesy, które od zawsze uważaliśmy za literackie $\mathrm{w}$ swojej naturze, są podbudową pospolitego umysłu. Takie literackie mechanizmy, jak stapianie czynią możliwe istnienie pospolitego umysłu"97. Dziwne jest jednak to nagminne wykorzy-

93 Tamże, s. 14.

94 G. Fauconnier i M. Turner, The way we think, New York 2002.

95 M. Turner, The literary mind, dz. cyt., s. 74.

96 Tenże, Reading minds..., dz. cyt., s. 121.

97 Tenże, The literary mind, dz. cyt., s. 115. 
stywanie przez badacza przymiotnika literacki na określenie procesów, które w żadnym razie nie należą wyłącznie, albo choćby przeważnie, do domeny literatury, choć zauważyć można też łatwość, z jaką Turner porusza się w swoich przykładach między literaturą, przysłowiami i codziennymi wyrażeniami. Trzeba jednak przyznać, że przytaczane przykłady literackie są frapujące. Obejmują one parabole ( $\mathrm{w}$ tradycyjnym tego słowa znaczeniu), bajki, zagadki i podobnie rzadko spotykane w literaturze typy tekstów. Czego dowiadujemy się, powiedzmy, o powieści realistycznej? Turner dzieli się celnymi spostrzeżeniami, mówiąc, jak powieści umożliwiają konstruowanie przestrzeni mentalnych do śledzenia zmieniających się punktów widzenia i wymagają ich. Wskazuje również na fakt, że to właśnie $\mathrm{w}$ stopionych przestrzeniach mentalnych powoływani są do życia bohaterowie literaccy ${ }^{98}$. Więcej takiego typu obserwacji na pewno życzyliby sobie czytelnicy zainteresowani bardziej kwestią literackiego niż umysłowego pierwiastka.

\section{Różnice i podobieństwa}

Pomimo naszych krytycznych recenzji uważamy, że Iser i Turner zasługują na uwagę. Już to, że ich rozprawy są szeroko dyskutowane w środowisku naukowym świadczy o ich dużym wkładzie w rozwój dyscypliny. Ich podejścia różnią się $\mathrm{w}$ wielu aspektach. Podsumujmy najpierw te różnice, by następnie przejść do podobieństw.

Generalnie Iser i Turner mają różne poglądy na kwestie pośrednictwa, intencjonalności, estetyki, świadomości i języka. Według badacza niemieckiego pośrednikiem jest najpierw tekst, potem czytelnik i to mimo że pierwotnym celem Isera było oddać procesowi czytania należne mu miejsce w badaniach literackich. Zdaniem Turnera przeciwnie - pośrednictwo jest zawsze domeną człowieka, nigdy rzeczy nieożywionych. Jak zauważa Richardson, „według Turnera kwestia pośrednictwa nie jest problemem, ale czymś oczywistym"99. Iser z kolei często zakłada równą czytelnikom, jeśli nie większą, moc pośredniczenia tekstów ${ }^{100}$, co prawdopodobnie wywodzi z tradycji hermeneutycznej, której celem było zrozumienie tekstu, a nie procesów mentalnych czytelników. Następną rozbieżnością pomiędzy badaczami jest kwestia intencjonalności. Iser ani

98 Zob. tamże, rozdział 7.

99 A. Richardson, Brains, minds, and texts: a review of Mark Turner's The literary mind, „Review” 1998, 20, s. 41.

100 W. Iser, The implied reader, dz. cyt., s. 279. 
razu nie definiuje czytania jako celowego lub intencjonalnego działania. Turner z kolei uważa, że każde poznawcze działanie jest celowe i intencjonalne - ucieleśniony umysł ludzki w ludzkim świecie musi rozumieć ten świat, by przetrwać (jak często twierdzi). Czytanie, czyli odczytywanie znaków wokół nas, jest jedną ze strategii przetrwania. $\mathrm{O}$ ile Iser chciałby w tym układzie przydzielić literaturze specjalną funkcję, o tyle Turner skłania się ku postawieniu znaku równości między wytworami literackimi a innymi aktami poznania.

Obie te postawy są odzwierciedlone w poglądach badaczy na estetykę i język. Iser czasami chce wierzyć w odmienność pierwiastka estetycznego od pierwiastka codzienności, natomiast Turner uważa, że obie kategorie są nieodłączne. Według badacza amerykańskiego literatura jest poznawcza, umysł - literacki, a granice pomiędzy obiema domenami sztuczne. Isera zauważa, że to, co literackie, nie jest ani pospolite, ani codzienne. Twierdzi, że czytanie współczesnych utworów fikcyjnych to unikatowe doświadczenie:

Za sprawą dwudziestowiecznej powieści proces czytania stał się jeszcze bardziej skomplikowany, ponieważ w tym gatunku odkrywanie dotyczy funkcjonowania naszych zdolności percepcyjnych. Czytelnik ma za zadanie uświadomić sobie naturę tych zdolności, uświadomić sobie swoją predylekcję do łączenia ze soba rzeczy w regularne wzorce i tak naprawdę zdać sobie sprawę z całego procesu myślowego stanowiącego jego relacje ze światem poza nim samym ${ }^{101}$.

W przeciwieństwie do Isera, Turner, nawiązując do formalistycznego pojęcia defamiliaryzacji, powiedziałby, że każda forma sztuki (a nie tylko współczesna fikcja) uzmysławia nam istnienie percepcji i poznania. Co więcej, nasza skłonność do konsekwencji w sposobie tworzenia znaczenia i nasza świadomość stosowania takiej praktyki to dwie różne kwestie. Wreszcie, bez względu na to, czy jesteśmy w pełni świadomi naszego nawyku łączenia i tworzenia relacji, czy nie, ma to niewiele wspólnego z prawdziwymi powiązaniami, jakich dokonujemy podczas czytania tekstów. Wiele $\mathrm{z}$ operacji zachodzących podczas czytania prawdopodobnie zawsze pozostaje nieuświadomione. Faktycznie nieufność, jaką Turner $\mathrm{w}$ The literary mind darzy „powolną, głupią świadomość”, jest jednoznaczna. Jego zdaniem, piękna umysłu trzeba upatrywać w jego dobrym, szybkim i łatwym działaniu, które umożliwia tworzenie znaczenia, gdy świadomość stoi na uboczu. To interesujące, że Iser wyczuwał to intuicyjnie, kiedy pisał o zadziwieniu nieokreślonością:

[...] w trakcie wyszukiwania regularności i schematów w tekście, możemy dojść do wniosku, że nasza „interpretacja” jest zagrożona samą obecnością innych moż-

101 Tamże, s. 14. 
liwych „interpretacji”, tym samym powstają nowe tereny nieokreśloności (choć możemy sobie z nich ledwie, jeśli w ogóle, zdawać sprawę, jako że nieustannie dokonujemy „wyborów”, które je wykluczają) ${ }^{102}$.

Jeśli Iser słusznie prawi na temat naszej nikłej świadomości, to kolejny raz ma coś wspólnego z Turnerem. Jednak co z tego, skoro swoim poglądem, że „dzieło literackie musi być postrzegane jako pewien rodzaj świadomości"103 znów rozmija się ze swoim amerykańskim kolegą.

Mimo dzielących ich różnic Iser i Turner są przecież badaczami ludzkiego umysłu, więc nic dziwnego, że istnieją między nimi podobieństwa. Pogląd naukowca niemieckiego nakreślony w The implied reader na temat naszej „skłonności do łączenia rzeczy w regularne wzorce”104 podczas czytania jest wsparty motywem połączeń, który przewija się przez całą Reading minds Turnera. Widać wyraźnie, że między oboma naukowcami istnieją związki. Iser ponownie punktuje, gdy w 1978 roku mówi, że znaczenie nie jest ukryte $\mathrm{w}$ tekście ${ }^{105}$, co pokrywa się ze stwierdzeniem Lakoffa i Turnera z 1989 roku o „znaczeniach [...] w ludzkich umysłach, nie w wyrazach zapisanych na stronie"106. Jeszcze więcej podobieństw ujawnia się przy okazji obserwacji, że przez lata różne tradycje teoretyczne posługiwały się innymi nazwami do opisywania podobnych zjawisk. Na przykład to, co Iser nazywa zintegrowaną całością (Gestalt)107 albo połączoną aktywnością umysłu108, jest prawdopodobnie analogiczne do Turnerowskiego amalgamatu czy stapiania się. Podobnie to, co Iser w 1993 roku nazywa fikcjami, zostanie trzy lata później określone przez Turnera jako opowieści. Niewątpliwie dalsze eksploracje zachodzenia na siebie retoryki kognitywnej i estetyki recepcji ukażą jeszcze więcej podobieństw między obiema teoriami.

Kolejny punkt styczny uwidocznia się w spostrzeżeniach Isera o czytelniku wypełniającym luki w procesie czytania. Jak pisze badacz niemiecki, „alteracje w projekcjach czytelnika” są jedynym sposobem na ustanowienie „udanej relacji między tekstem a czytelnikiem” na przekór istniejących między nimi „luk” i „pustych przestrzeni”109. Luki są struk-

102 Tenże, The act of reading..., dz. cyt., s. 287.

103 Tamże, s. 293.

104 Tenże, The implied reader, dz. cyt., s. xiv.

105 Tenże, The act of reading..., dz. cyt., s. 13.

106 G. Lakoff i M. Turner, More than cool reason: a field guide to poetic metaphor, Chicago 1989, s. 109.

107 W. Iser, The act of reading..., dz. cyt., s. 186.

108 Tenże, The fictive..., dz. cyt., s. 181.

109 Tenże, The act of reading..., dz. cyt., s. 167. 
turami „stymulującymi czytelnika do uzupełniania pustych przestrzeni poprzez projekcje"110, a zatem mogą być synonimiczne z terminem ukończenia wzoru ukutym we wczesnym konekcjonizmie, tj. jednej z podbudów nauki o poznaniu, jakie podpierają wysiłki Turnera na polu językoznawstwa kognitywnego. Prawdopodobnie Isera i Turnera łączy jeszcze więcej na najbardziej ogólnym poziomie badań - kwestii umysłu literackiego. Retoryczne pytanie Isera o to, jakie „nowe podwoje otwiera literatura przed naukowcami zajmującymi się mechanizmami działania ludzkiego mózgu"111, które zresztą równie dobrze mógłby sobie zadać Turner, to zapowiedź badań kognitywnych pod auspicjami badacza amerykańskiego. O ile takie antropologiczne podejście było typowe dla Amerykanina od samego początku jego naukowej działalności, to Niemiec dochodził do takich wniosków stopniowo. Niemniej jednak to właśnie zainteresowanie Isera $\mathrm{w}$ latach dziewięćdziesiątych antropologią literatury zwiastowało obecny kierunek badań krytyki kognitywnej, który wyznacza psychologia ewolucyjna i antropologia poznawcza ${ }^{112}$.

\section{Wnioski: ku teorii recepcji kognitywnej}

Śledząc korzenie krytyki kognitywnej w teorii recepcji, próbowaliśmy ukazać, jak ta pierwsza bezkolizyjnie podąża ścieżką tej drugiej i to mimo teoretycznych rozbieżności między Iserem i Turnerem, braku wzajemnych cytowań i istotnych bibliograficznych luk między podejściami. Naszym celem było także zasugerowanie, że jeśli teoria recepcji miałaby nie zatracić swojej użyteczności, musi wykonać zwrot ku kognitywizmowi. Ten proces jest już w toku, jak można zauważyć na podstawie prac Gerriga, Mialla, Mialla i Kuikena, Oostendorpa i Zwaana oraz Zwaana113. Ważne, żeby tych badań nie przerywać. Ze swojej strony Iser słusznie

110 Tamże, s. 168.

111 Tenże, Prospecting..., dz. cyt., s. 6.

112 Zob. m.in.: J. Carroll, Literary study and evolutionary theory: a review essay, „Human Nature” 1998, 9, s. 273-292; F. Steen, „It's for pretend: toward a communicational theory of entertainment", wykład na UCLA z dnia 19.12.1999 roku; R. Storey, Mimesis and the human animal, Chicago 1995.

113 Zob. m.in.: R. Gerrig, Experiencing narrative worlds: on the psychological activities of reading, New Haven 1993; D. Miall, Anticipation and feeling in literary response: a neuropsychological perspective, „Poetics” 1995, 22, s. 275-98; D. Miall i D. Kuiken, Foregrounding: defamiliarization, and affect: response to literary stories, „Poetics” 1994, 22, s. 389-407; H. van Oostendorp i R. Zwaan (ed.), Naturalistic text comprehension, Norwood 1994; R. Zwaan, Aspects of literary comprehension, Amsterdam 1993. 
rozumował, gdy stwierdzał, że naprawdę ważkim i trudnym tematem badań jest „nie istota znaczenia, ale to, jak jest ono wytwarzane” 114 . $\mathrm{Z}$ tym Turner by się zgodził, ale sam problem i tak pozostaje nierozwiązany. Nawet jeśli nie, to Iser utorował drogę dla dalszych rozważań na polu teorii recepcji. Po zwrocie kognitywnym pytania, jakie sformułowała Rezeptionäesthetik w przeszłości, dotyczące z jednej strony poznawczych i afektywnych warunków procesu czytania, a z drugiej wpływu i ograniczeń czytania literackiego, muszą być ponownie podjęte, pomimo postępów poczynionych ostatnimi czasy przez krytyków kognitywnych. Nauka o poznaniu generalnie ma możliwość zaktualizowania teorii recepcji, ale to szczególnie psychologia kognitywna powinna ułatwiać kształtowanie teorii recepcji kognitywnej. Takie odświeżenie, jak uzmysławiają nam to Iser i Turner, jest obecnie na pewno możliwe i niezbędne.

\section{Przełożył Mateusz Marecki115}

114 W. Iser, Prospecting..., dz. cyt., s. 65.

115 Przekład artykułu Craiga Hamiltona i Ralfa Schneidera był możliwy m.in. dzięki projektowi współfinansowanemu przez Unię Europejską w ramach Europejskiego Funduszu Społecznego.

KAPITAL LUDZKI

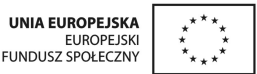

